\title{
Theology in the flesh - a model for theological anthropology as embodied sensing
}

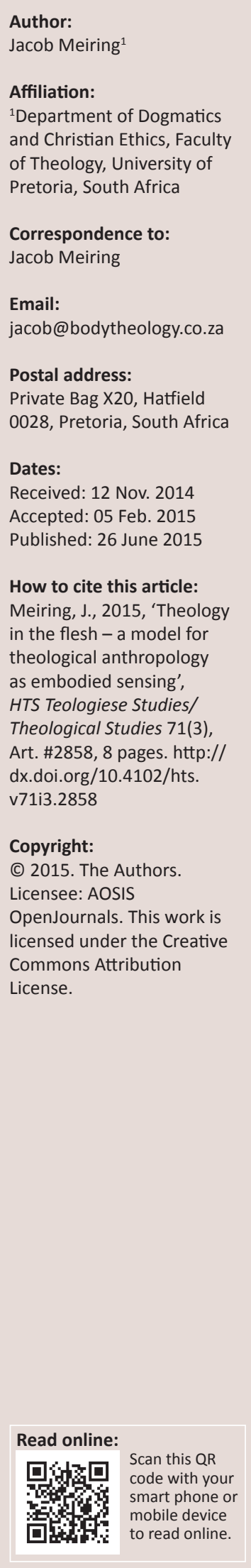

The author proposes a model for theological anthropology as embodied sensing that is based on an interdisciplinary exploration of the corporeal turn from a southern African perspective. The work of James B. Nelson is acknowledged, stating that body theology starts with the concrete, the bodily expressions of life and not with doctrines about God and humanity. The theological anthropology of David H. Kelsey is evaluated as a theological anthropology with a sentiment of the flesh. Based on clearings in the work of David Kelsey and an interdisciplinary research, the author proposes a model for theological anthropology as embodied sensing which functions within the intricate and complex connection of the living body, language and experiencing in a concrete lifeworld with an openness to the 'more than'. The author considers the use of bodymapping within narrative therapy as a way in which to uncover the intimate and intricate connection between the living body, experience and language, and implementing insights from theological anthropology as embodied sensing.

\section{Introduction}

Artists in the 18th century had an obsession with the flesh. The challenge was to capture the colour of skin on canvas. The French philosopher and art critic, Dennis Diderot, writes in his Essay on Painting that the realism in a painting derives from form and that life originates from colour, stating that:

$[H]$ e who has acquired the feeling for flesh has progressed a lot; the rest is nothing in comparison. Thousand painters have died without knowing flesh; thousand others will die without feeling it. (Diderot 1795 cited in Rabaté 1996:34)

This was paraphrased in the 2010 film, Le sentiment de la chair [The sentiment of the flesh], with the remarks that 'a thousand painters died not knowing the sentiment of the flesh. Many more will die not knowing' (Smells like screen spirit 2011). Therein lies the challenge for theologians - to know the sentiment of the flesh.

The quest in my research is for a theological anthropology that can reflect a deeper understanding of the rich and complex dimensions of bodily life; a theological anthropology that has a sentiment of the flesh. In proposing a model for theological anthropology as embodied sensing, I have explored the corporeal turn from a southern African perspective in an interdisciplinary conversation with other disciplines like sociology, philosophy, somatic psychology, paleoanthropology, cognitive science and molecular biology, weaving them together with the voices of Church Fathers, mystics, Protestant Reformers, artists and novelists. A postfoundationalist theology opens the door very wide to an interdisciplinary dialogue, and especially in the context of initiating deeper and deeper levels of inquiry into the body and the experiences of the body within a specific and concrete lifeworld.

\section{The body - a South African perspective}

While the obsession in the 18th century was mostly with white skin, the morbid fascination in the 19th century was with black flesh; the beginning of an era of 'the new pseudo-science of ethnology' that went hand in hand with white imperialism, the economic exploitation of colonies, and scientific racism (Holmes 2007:70). The public exhibition on Piccadilly, London of 'The Hottentot Venus' was probably the most prominent body on display of a black woman (as colonial subject) in the 19th century and remained so till 1976 when her skeleton and body cast were removed from public display at the Museum of Natural History in Paris (Holmes 2007:65). Lahoucine Ouzgane (2002), a scholar in postcolonial theories, writes that this way of pathologising the black body through the process of 'othering' was done to elevate the European as superior and different to other races. White bodies were considered to be civilised and controlled, whereas 
black bodies were portrayed as 'oversexed and savage'. To maintain the 'truth' of the structures and institutions of these colonial empires, black bodies were disciplined (including torture and death) and made docile. After the 19th century, 'this surveillance was an internal and external mechanism of docility' that was used by white people to determine what was possible for black bodies, and when necessary also for white bodies (Ouzgane 2002:244). It was a mission that was implemented also during apartheid through paternalism, brutality, force, arrogance, humiliation, and deep insensitivity.

A well-known attempt to clear society of the monstrosities of apartheid was made in the form of the Truth and Reconciliation Commission (TRC) under the chairmanship of Archbishop Desmond Tutu. The 'descriptions, representations and conflicts around bodies in various states of mutilation, dismemberment, and internment within the terror of the past' were the 'visual core' of the TRC (Bethlehem 2006:82). Family members repeatedly pleaded for the remains or body parts of their loved ones, 'making their visibility, recovery and repossession a metaphor for the settlement of the past of apartheid' (Bethlehem 2006:82). The 'moral signature' of the TRC was the employment of two visual 'tools', namely the practice of exhumation and 'of one body held by another' (Bethlehem 2006:83). The focus on the body during the TRC hearings delivered a 'mnemonic production' where the surface of the body became a site of memory. The sight of the violated body allowed the body to be 'stabilised as the site of memory' (Bethlehem 2006:85). The pain of the body is shared.

The sociologist Didier Fassin (2007) writes that the body is not just a manifestation of a person's presence in the world, but it is also a site where the past has left its mark or as he puts it:

[T] he body is a presence unto oneself and unto the world, embedded in a history that is both individual and collective: the trajectory of a life and the experience of a group. (p. 175)

Any contemporary theological anthropology in South Africa should have a profound consideration for the bodily experiencing of black people in their concrete life worlds throughout the heart-wrenching history in South Africa, from the time of the first explorers and missionaries in the 15th century, the colonial and apartheid periods and in postapartheid South Africa. There is an implicit kind of bodily knowing in the continuous interaction of living bodies with their environment throughout this 500-year history, a bodily knowing where the black body has often been denied its dignity and humanity, where it has been perceived as subhuman and uncivilised.

\section{The corporeal turn in theology and theological anthropology}

Was there really something like a 'corporeal turn', a conceptual shift that happened some time during the 20th century? In her book, The corporeal turn (2009), Maxime Sheets-Johnstone writes that the humanities and human sciences were the spawning ground of two fundamental conceptual shifts in the twentieth century: the earlier linguistic turn and the later corporeal turn' (Sheets-Johnstone 2009:2). The Austrian-born philosopher, Ludwig Wittgenstein set in motion a linguistic turn, followed by several other linguistic turns in early 20th century, between the First and Second World Wars. Soon after, French philosophers and the phenomenological movement laid the foundation for the corporeal turn. In the late 1940s and 1950s French philosophers, such as Maurice Merleau-Ponty, Gabriel Marcel and Michel Foucault put the body at the centre of the ontological problem and in this way, initiated the corporeal turn. The 1960s and 1970s were also the decades when great value was placed on the body in social life; in the 1980s, feminist theology, black theology, liberation theology, queer theories and the HIV and AIDS epidemic further impacted on the social regulation and construction of the bodies of women, black people, impoverished people, and of gay men and lesbian women. The application of bodymind therapies within somatic psychology were greatly influenced by the cultural changes of the 1960s.

My own argument would be that one could refer in broad terms to the corporeal turn (1940-1965), followed by a second wave (1976-1986), and a third wave (1990-2000). Perhaps it would also be feasible to speak of second and third generation corporeal turns. The second generation corporeal turn appears to be a tentative application of the insights from the post-war French philosophers in other disciplines such as sociology, psychology and theology. It also seems that it had a limited interdisciplinary scope. From research conducted within cognitive science, I note a 3rd generation corporeal turn with a striking feature that points to a convergence of the linguistic and corporeal turn, also as a result of cognitive linguistics with an emphasis on how language develops from the body, and the influence of metaphorical thinking. I would refer to this 3rd generation corporeal turn as a corporeallinguistic turn. Once again, philosophy has set the pace with the work of authors like Eugene Gendlin, Thinking beyond patterns: Body, language, and situations (1991), George Lakoff and Mark Johnson, Philosophy in the flesh (1999), and Horst Ruthrof, The body in language (2000).

The question can also be asked whether one can truly talk about a corporeal turn in theology in the same way that one refers to it within other academic disciplines, or is there another dynamic at play? What is clear at this point is that the body became a contentious topic in the church of the 20th and 21st centuries in the wake of the sexual revolution that was sparked by, amongst others, the work of Wilhelm Reich in the 1930s. This revolution reached its culmination in the 1960s, 1970s and early 1980s when its momentum was stumped by social, economic and political factors - the HIV and AIDS epidemic being one of them. There is an indication of the far-reaching influence of the French phenomenological philosophers after the Second World War, also in theology, and especially in the development of a theology of the body within Roman Catholic and Protestant churches. 
Pope John Paul II wrote the manuscript, Man and women He created them in Polish in the 1970s when he was Cardinal Wojtyla; it formed the basis for the development of his theology of the body through his Wednesday catechisms from 1979 to 1984. In parallel, James Nelson formed his ideas for his book, Embodiment: An approach to sexuality and Christian theology (1978), while the Roman Catholic theologian, Benedict Ashley (1985) published his book, Theologies of the body: Humanist and Christian in 1985. The pope's theology of the body had a continuous influence from its first publication.

Nelson's (1978) work was influential in my quest for a theological anthropology that takes the body seriously. He repeats the assertion in his 1978 book that 'body theology begins with the concrete' and not with doctrines or creeds or problems in tradition. It begins with the concrete and 'the fleshly experience of life - with our hungers and our passions, our bodily aliveness and deadness' (Nelson 1992:43). He considers 'lived experience' to be the most neglected in theology and writes that for many, theology is a 'second moment' and that the first moment is 'life itself', that 'theology comes afterward, attempting to understand and serve life'(Nelson 2004:12).

The notion of the body and embodiment - not in the format of body theology - appears again in the late 2000s in the work of theologians like Wentzel van Huyssteen's (2006) who explores human uniqueness and personhood; Wesley Wildman's (2009) who advocates a religious naturalist anthropology; non-reductive physicalism in the work of Nancey Murphy's (2006); the relational theological anthropology of F. LeRon Shults (2003); an African Christo-theological anthropology of the Tanzanian theologian Andrea $\mathrm{Ng}^{\prime}$ wesheni (2002) and Anthony Pinn in his book, Embodiment and the new shape of Black theological thought (2010).

In his monumental book, Eccentric existence: A theological anthropology, David Kelsey (2009) wholeheartedly embraces the notion of the human body as a personal living body that can flourish to the glory of God. Kelsey (2009) emphatically states that:

[T] he real you is none other than this living human body that has been born of particular parents at a particular time and place in a particular society with its particular culture. (p. 285)

He does not believe in the Fall or in the existence of a historic couple such as Adam and Eve. Kelsey is also very suspicious of the overemphasis of 'the interior psychology of $\sin$ ' as introduced into theology by Augustine through his notion of the inner man. Instead, he appeals to humans to be wise in their practices in the way they interact with other humans, with social institutions and other non-human creatures.

Kelsey (2009:162) alludes to the 'textures of life' when he refers to the created proximate context as 'humankind's lived world in its concrete everydayness', and the dignity that is inherent to this everydayness, where the perfect, real and authentic human is the 'ordinary everyday human person.'
He alludes to the 'textures of a fleshly world' when he sees the proximate context as 'inherently ambiguous' - filled with 'the possibility of our well-being' as humans and at the same time holding the potential of pain, loss and death (Kelsey 2009:202). He acknowledges this textured life when he anchors his theological anthropology in the doctrine of creation and in the practical wisdom of Job.

\section{A model for theological anthropology as embodied sensing}

Keeping in mind the limitations in the focus of body theology and theology of the body, as well as the clearings identified in the theological anthropology of David Kelsey (a wider incorporation of the corporeal-linguistic turn from other disciplines, as well as other theological anthropologies, and the recognition of bodily experience as a source of revelation and knowledge), I propose a model (see Figure 1) for theological anthropology as embodied sensing (Meiring 2014:283).

A contemporary theological anthropology with a sentiment of the flesh and a sensitivity to the textures of life functions within the intricate and complex connection of the living body, language, and experiencing in a concrete lifeworld. The 'more than' in the model can express a variety of ideas and concepts, expressing amongst others the notion of eccentric existence in the Trinitarian theological anthropology of David Kelsey. The word 'sensing' is an effort to move away from the subject and object distinction to a more participatory approach and, as Eugene Gendlin (1997:15) phrases it, 'to speak from how we interact bodily in our situation'. It is, however, quite difficult to bypass the subject and object distinction altogether, since we obsessively tend to objectify ourselves, other creatures and events in our concrete situation. The 'more than' is also an attempt to illustrate that we are 'more than' the obsessive objectifying of

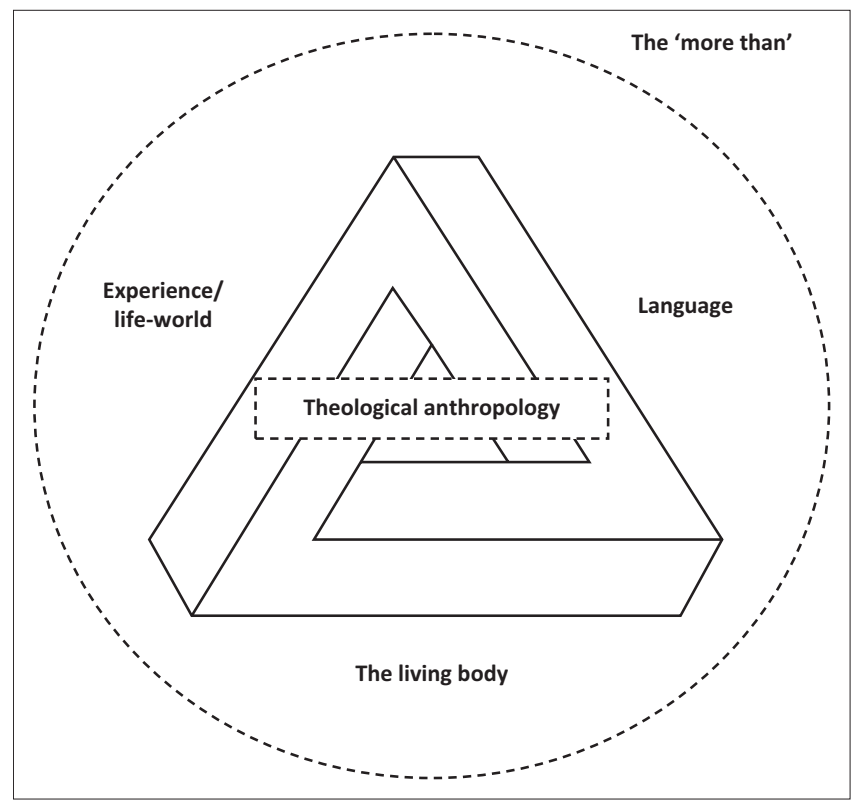

FIGURE 1: A model for theological anthropology as embodied sensing. 
objects, events and each other. It is furthermore an effort to express the notions of sentiment of the flesh and sensitivity to the textures of life. It moves away from a pure cognitive, objective approach to sensing, derived from the Latin word sensus, which expresses the faculty of thought, feeling and meaning.

The term 'sensing' endeavours to capture what Gendlin (1996) conveys with the word 'focusing' and Todres with the expression 'embodied understanding'. Todres (2011:2) defines 'embodied understanding' as 'a form of knowing that evokes the possibility of living, bodily relevant textures and meanings.' He in turn builds upon Gendlin's (1996) notion of focusing, which is about paying attention to the words that work, responding to an experience where language captures the felt sense of a word in the body. It is a focus on texture where a phenomenon is not merely a theoretical description of an occurrence, but a live moment that was embodied by a person in a concrete situation.

\section{The living body}

A clearing exists in Kelsey's theological anthropology to incorporate insights from other academic disciplines into the notion of the living body. It also illustrates the necessity of continued interdisciplinary dialogue in the ongoing process of further developing and expanding the notion of the living body. It is therefore necessary to fill this clearing in Kelsey's theological anthropology with the insights gained from other academic disciplines. These insights include:

- An acknowledgement of the species-specific placement of humans in history, and our common creaturehood with other primates.

- An understanding that the evolution of language is only possible within the context of a sensory-kinetic world.

- The notion that sexuality, imagination and morality are intimately linked to the embodied evolutionary nature of humans.

- The notion that our moral dimensions are linked to our prehistoric roots, and our moral concepts (for example freedom, compassion, justice, tolerance, and virtue) are structured metaphorically. These moral metaphors have a grounding in our bodies and in our social interactions.

- The notion that mirror-neurons in the brain provide a strong explanation of how the perception of the emotion in one individual activates neural mechanisms in an observer, allowing the observer to resonate with the emotional state (empathy) of the individual being observed. Interpersonal neurobiology (IPNB) indicates how human patterns of attachment are shaped by the processes of neural systems and these attachments shape neuron patterns.

- The notion that the body can also be referred to as a system of 'meaning-seeking', which constantly interacts with its environment in an effort to seek coherence.

- The notion that the body is always consciousness embodied, meaning that the embodied mind is part of a living body and human cognition is not only driven by the experiences of the body, but also the crucial role of the body in providing resources for cognition.

- The notion that body image and body schema or the later concept of corporal-kinetic intentionality and corporalkinetic patterning are aspects of the 'meaning-seeking body'.

- The notion that the whole body stores memory, including traumatic events, which research in molecular biology has found can be inherited from previous generations.

- An acknowledgement of the fundamental importance of touch for the physical, emotional, social and moral flourishing of humans, that is, the expression of tactile interaction is essential for the developing brain.

- The notion that bodymind therapies can create an awareness of the intricate relationship between our bodies and our lifeworlds, and open us up to the wisdom of our embodiment, and a sense of belonging with our bodies, that is, to be the bodies that we are. The body, therefore, can never merely be a vessel for the disembodied mind.

Kelsey further develops the notion of the living body into the 'personal body' and 'flourishing body'. It can be expanded to include, for example, the notion of the vulnerable body when speaking of sin, and how people carry trauma and other memories in their bodies, also from generation to generation. It is from this deeper interdisciplinary enquiry into the body that it is possible to reconstruct and reform certain doctrines (Meiring 2014:288).

\section{Language}

It is clear from the exploration of the corporeal-linguistic turn that there exists a very close relationship between language, the body, and experiencing; it is sometimes a difficult and forced exercise to discuss these in isolation from each other. Kelsey is keenly aware of the importance of language in wisdom literature and the normative connection between the correct use of language and complex practices. He views humans as the social, intentional, bodied enactors of complex practices that include the use of language. Language is then an integral part of wise practices in which it is used in such a way, that it remains true to the nature and purpose of the relevant practice, and responds to the realities of the larger public context. According to Kelsey (2009:199), it is very important that language is not in a way that is false or deceitful, since distorting the practice through the deceitful use of language is to deform the quotidian created by God. He also acknowledges the interchange between a living body and its capacity for language, and the way in which language is intimately connected to a culture's rituals, myths, symbols, and images (Meiring 2014:288).

A contemporary theological anthropology that takes the body seriously should also incorporate the insights from paleoanthropology and linguistic philosophy with regard to the role of language and the intimate connection with the body and experiencing. The ability to walk upright is the defining moment in hominid evolutionary history, since the ability to use signals and language developed from this and, 
in turn, the human brain has been reorganised in response to language. Linguistic philosophy has focused the attention on the challenge in languaging human experiences, and the effort it takes to stay true to the truth of experiences through the use of language. The living body is part of language as a discourse, which Gendlin (1997:28) expresses in his assertion that 'speaking is a special case of bodily interaction.' According to Gendlin, the body has an implicit knowing function that includes knowing the language, and how it is relevant to a concrete situation. This kind of bodily knowing (which includes language) is about a living body continuously interacting with its environment. Gendlin (1997:27) also makes the assertion that the living body is its own next step, that 'a living body is a self-organizing process' in the sense that it implies its next bit of life process. The challenge is to move beyond the subject and object distinction and to speak from how we interact bodily in a specific situation, trying to express the bodily sense of living in a concrete lifeworld, speaking from a 'sensed experience'.

\section{Experiencing in a concrete lifeworld}

A second clearing that exists in Kelsey's (2009) theological anthropology and in other contemporary theological anthropologies, is the lack of recognition of experience as a source of revelation and knowledge. Body theology, under the influence of liberation theology has brought this crucial aspect to the fore. Nelson (2004) views human bodily experience as important theological data in contemplating the reality of God, and describes it as the 'first moment' with theology being the 'second moment'. If theology or theological anthropology as 'second moment' should incorporate bodily experiences in a concrete lifeworld (experiencing) as important theological data, the way in which we listen to the 'voice' and wisdom of the body would be the challenge. It is not only about accumulating facts about the body, and what happens to the body under certain circumstances, but also how to access these bodily experiences, and how to language these experiences into theological words or concepts or doctrines. It is easier to make theological statements on how to live in the body, than listening to the body and from there reflect about human existence and the reality of God. The challenge in the latter position lies in the ability to put theological judgements and statements aside and to listen to interior dynamics of human bodily experience and the body as a 'sense-making process' (Meiring 2014:290).

Theological anthropology as embodied sensing endeavours to capture this process of sense-making as an equal and authoritative source of revelation and knowledge on par with tradition and scripture. Eugene Gendlin (1997:32) asserts that 'experiencing is inherently sense-making', and that sense-making is implicitly symbolised in the interactional events with other human and non-human creatures. These events are then elaborated through language which Gendlin refers to as 'eventing'. His conclusion is that there can be no sense-making without experiencing and eventing, and in the context of Nelson's argumentation there can be no sensemaking of existence before God without experiencing and eventing (the elaboration of experience through language). And if all experiences are grounded in the body, the intimate and intricate connection between the living body, experience, and language is uncovered and it is within this intimate relationship that a contemporary theological anthropology as 'second moment' develops its enquiries and articulations.

Theological anthropology as embodied sensing should also be aware that not all bodily experiences can be adequately captured in the cognitive units of theological language, that some experiences could probably never be analysed through the use of language, and that they could only be 'sensed' through further living. Todres (2011:20) expresses this inability to language all experiences by referring to the body in its lifeworld 'as the messenger of the unsaid'. Gendlin refers to the 'felt sense' of bodily experiences, whereby he not only expresses the feeling of 'the stuff inside', but 'the sentience of what is happening in one's living in the outside' (Gendlin 1997 cited in Todres 2011:23). The challenge for a contemporary theological anthropology as embodied sensing is to capture this embodied experiencing, the 'felt sense' of bodily experiences, and to listen to the 'unsaid' of the body. Then theological anthropology as embodied sensing truly has a sentiment of the flesh and a sensitivity to the textures of life (Meiring 2014:291).

\section{The 'more than'}

The 'more than' can refer to a variety of ideas or concepts, or theological thought experiments and articulations. David Kelsey refers to the 'epistemic mysteriousness' of living human bodies, that not all manner of knowing of the human body can be exhausted, and that the Trinitarian formula of humans being created by 'the Father through the Son' grounds our knowability 'in the very life of God' (Kelsey 2009:268). Living human bodies are amazingly complex and in this sense they are 'inexhaustible objects of knowledge.' This ties in with what Todres describes as 'the unsaid' of the human body and the idea that not all human bodily experiences can be languaged. Todres (2011:185) also expresses the 'unsaid' in the idea that the experiences of spirituality in everyday life 'are grounded by the palpable lived experience of meeting a mystery that is always in the excess of the known.' His concept of the living body is that it is not merely an object encapsulated by skin, but that it is a subjectivity that is 'intimately intertwined with what is there beyond the skin.'

There is a 'more than' to the eventing of human bodily experiences in a concrete lifeworld; there is a 'more than' to the richness of textured bodily life that cannot easily be conveyed into theological articulations. Kelsey (2009:544) expresses this 'more than' in the notion of eccentric existence, and the continuity between physical human bodies and glorified bodies as 'God-related bodies', living in 'the sociality of community-in-communion' where they are recognisable as an individual with unconditional dignity and unqualified respect. Kelsey (2009:1009) describes Jesus Christ as 'uniquely God-related', and it is as the 'imagers of 
the image of God' that humans are finite living mysteries that image the triune living mystery.

Kelsey (2009:546) writes that there is a discontinuity in the 'mode of bodiliness' of the pre- and post-Easter Jesus. He cites Hans-Joachim Eckstein to point out that canonical narratives make it clear that:

$[T]$ he living human personal body, identified with the preEaster Jesus, who is encountered post-Easter is a transfigured or glorified body that is in important ways discontinuous with the pre-Easter Jesus' body. (p. 546)

He continues that Paul writes in 1 Corinthians 15:50 that 'flesh and blood cannot inherit the kingdom of God, nor does the perishable inherit the imperishable', meaning that only a glorified body can inherit the kingdom of God. Jesus is not resurrected into his previous, physical body 'tied to quotidian space, time and matter', but is raised 'into the borrowed time of God's eschatological future' as a mark of the proleptic intrusion of the eschatological reign of God into human creatures' quotidian proximate contexts' (Kelsey 2009:546). He continues to draw two implications for theological anthropology. The first is that the resurrected body of Jesus should not be confused with a resuscitated body (like those of Jairus' daughter or the widow's son in Nain or Lazarus). They are considered as resuscitations and do not have 'the significance of being the concrete way in which God inaugurates fulfilment of eschatological blessing.' The second implication is that 'bodily resurrection as eschatological transfigured or glorified bodies is social and communal. The adopted human brothers and sisters of Jesus share in the same eschatological consummation since the 'fulfilment of God's promise of eschatological blessing has actually been inaugurated in the bodily resurrection of Jesus. Jesus is resurrected in and with community (Kelsey 2009:547). The bodily life of Jesus is more than the pre-Easter life in his body. This 'more' lies in the proximate context of the bodily resurrected Jesus (and ours) which Kelsey (2009:550) describes as 'a new heaven and earth where they live as glorified human bodies in a proximate context constituted by networks of interrelationships with fellow creatures.' He refers to John Polkinghorne (cited in Kelsey 2009:550), who writes that there is sufficient discontinuity to ascertain that the new creation is not just a redundant repetition of the old.' Kelsey (2009:550) continues that the 'more' is also captured by the otherness of the new creation which is discerned by 'justice, peace and love that characterize the community-in-intimate-communion that constitutes the life of the triune God.'

Even though Kelsey (2009:552) admits that there are 'virtually no grounds' for proposals with descriptions of a 'glorified human personal bodily life and its proximate context' without bordering on 'fantasy pictures' of life in a new heaven and earth promoting various forms of piety, he nevertheless puts forth proposals about the 'fully actualized eschatological consummation of human personal bodies in community' (Kelsey 2009:553). He bases his concept on the internal logic of Christian beliefs with an effort to 'steer imaginative speculation away from the more misleading and dangerous fantasies' (p. 553). He formulates his concept at the intersection of descriptions of an actual living human personal body in community, the minimal conditions that should be met according to evolutionary biology of what constitutes 'life', the 'logic of relations' among theological claims, and being guided by the 'dialectic between the continuity and discontinuity of the post-Easter Jesus and preEaster Jesus.'

\section{Exploring embodied sensing through bodymapping}

One of the ways in which I have endeavoured to uncover the intimate and intricate connection between the living body, experience, and language as well as the 'more than' ('the mystery of unsaid'), is through the use of bodymapping in narrative therapy. The challenge lies in languaging human experiences, and the effort it takes to stay true to the truth of experiences through the use of language; to find the words that work.

The motivation for me as a narrative theologian and therapist is to listen to the stories of people as expressed through their bodies. Jane Solomon (2007:2-3) describes bodymapping as a way of telling stories and making art about a person and his or her life (Figure 2).

The Memory Box Project at the University of Cape Town started running Memory Box workshops in Khayelitsha in 2002 (Bodymaps n.d.). Memory work is used with people with HIV and AIDS helping them to prepare for their own deaths and leaving their story behind for their children. In these workshops, facilitators discovered that people who were undergoing antiretroviral therapy (ART) treatment, were more future orientated than looking at the past. A large group of people had begun to draw their life stories, hoping to live longer. Flowing from this discovery, Jonathan Morgan and Jane Solomon developed the bodymapping process which resulted in the writing of the 'Living with $X^{\prime}$ a bodymapping facilitator's manual (Meiring \& Müller 2010:4 of 7).

The suggestion was made that the bodymapping process could have other applications for example, people with eating disorders or people living with chronic pain (Brett-MacLean 2009:741). It made me very curious to explore the possibility of using bodymapping in my work as narrative theologian. Another research project was centred on the question of how people make sense of physical trauma through their experience of bodymapping (Meyburgh 2006:6).

The notion of body memory refers to:

[A]ll the implicit knowledge, capacities and dispositions that structure and guide our everyday being-in-the-world without the need to deliberately think of how we do something, to explicitly remember what we did, or to anticipate what we want to do. (Koch, Caldwell \& Fuchs 2013:82) 


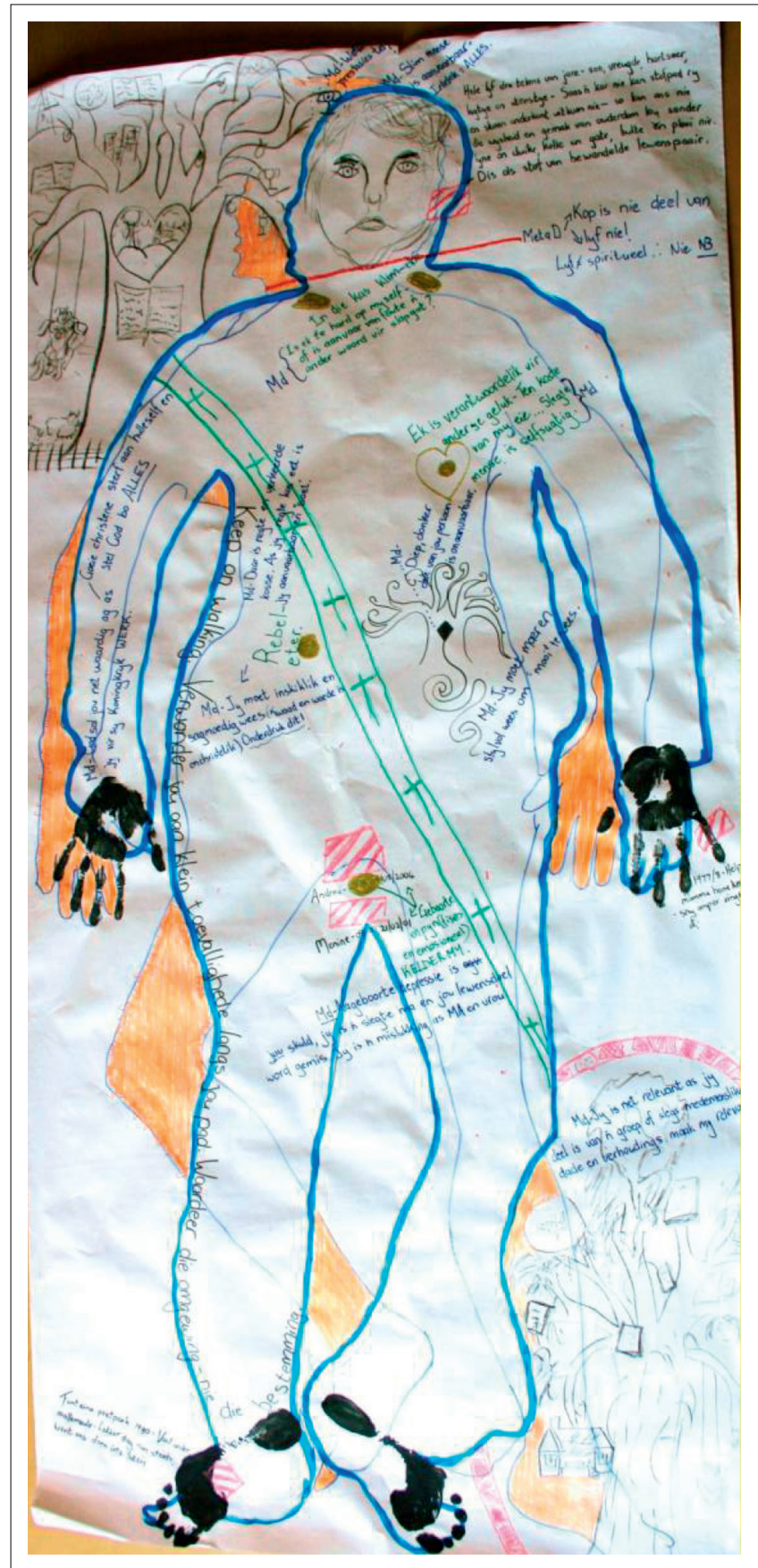

Source: Meiring, J.J.S., 2014, 'Theology in the flesh: Exploring the corporeal turn from a southern African perspective', PhD dissertation, Faculties of Theology, Vrije Universiteit, Amsterdam, University of Pretoria, Pretoria.

FIGURE 2: Body map of a co-researcher.

This kind of knowledge is accumulated 'in the course of our embodied experiences', especially in early childhood; the knowledge is then transformed throughout our life. There are six forms of body memory, including habitual or procedural body memory (habitual memory which enables us to acquire sensorimotor skills); situational body memory (this is atmospheric memory and the memory of interior and exterior spaces); inter-corporeal body memory (a bodily knowing of how to deal with others); incorporative body memory (the adaption of poses, manners and gender roles based on family and cultural environments); pain memory (the impact on physical painful experiences on the present moment); and traumatic memory (the impact of traumatic experiences on the present) which is stored in the body (Koch et al. 2013:83).

In her work on bodymapping, Meyburgh (2006) cites the geneticist and professor in biophysics, Mae-Wan Ho, writing:

There is no doubt that a body consciousness exists prior to the 'brain' consciousness associated with the nervous system. The body consciousness has also a memory. The relevant transmission system is called proton jump-conduction which belongs to a form of semi-conduction in condensed matter, and is much faster than conduction of electrical signals by the nerves. Thus the 'ground substance' of the entire body has a much better intercommunication system than can be provided by the nervous system alone. (p. 13)

I have recently encountered the work of the neuroscientist Antonio Damasio, who also uses the term 'bodymapping' in his research. He employs it as a term to describe the process in which the body interacts with its environment and how changes caused in the body by this interaction are mapped in the brain (Damasio 2012:91). He continues that 'the representation of the world external to the body can come into the brain only via the body itself, namely via its surface' (Damasio 2012:91; italics original). The body employs a variety of signals (chemical and neural) to send messages to the brain. This body-to-brain communication can be mapped very simply for example, by the mapping of the position of a limb in space, but a significant part of this signalling is initially channelled via the spinal cord and brain stem (Damasio 2012:92). He writes that facets of the function and physical structure of the body are engraved in brain circuitry meaning that 'some version of the body is permanently re-created in brain activity' (Damasio 2012:93). It would be a fascinating topic for future research to explore brain-to-body signalling (Damasio's bodymapping) with bodymapping as a narrative tool combined with the insights of theological anthropology as embodied sensing.

\section{Impressions from the body maps of co-researchers and clients}

Flowing from the use of bodymapping as a narrative tool during research and counselling, I have the following impressions:

- A dominant theme which surfaced was around acceptance and rejection, connected to concepts of heaven and hell resulting in strong feelings of guilt, especially regarding sexuality and bodiliness. This in turn manifested in the body by way of eating disorders, stress, sexually alienating behaviour and dissociation from the body.

- Experiences of rejection were also linked to extremely dominant metadiscourses of what it means to be a good wife, a good mother, a pretty woman, an attractive man, the typical male. The language of these metadiscources is grounded in that of a patriarchal heterosexism. My impression was that it causes a lot of anxiety and confusion regarding personal identity. These same 
patriarchal heterosexist metadiscourses had an almost unbreakable hold on male and female clients' image of God as purely male.

- Isherwood and Stuart (1998:96) write about the epistemology of the flesh as body knowledge. I do think that bodymapping can give voice to, for example, stories of oppression. The bodymapping process is extremely rich in metaphors and symbolism and ties in beautifully with the concept of externalisation in narrative therapy.

- Bodymapping is a powerful medium to create awareness regarding dominant metadiscources in society and it can be used to facilitate a process of body integration, overcoming various forms of oppression.

- Bodymapping could assist in the body and spiritual integration (Meiring \& Müller 2010:6 of 7).

\section{Concluding remarks}

The body matters. The history of South Africa and the African continent is rich in narratives of how bodies have been abused, but were also used as a 'site of resistance' against various forms of oppression, discrimination and alienation. This intricate relationship between the living body, language, experiencing in a concrete lifeworld and the 'more than' as expressed in the notion of theological anthropology as 'embodied sensing', is more complex than the incorporation of facts about the body into secondary theology in the process of reformulating doctrines in a theoretical and cognitive fashion with various applications in primary theology, for example moral theology or Christian ethics. It is about the sensing (feeling, thinking, meaning-making) of words about God (scripture, doctrines and tradition), and how it resonates with a lived body in a concrete situation, and how the experiencing of that body in its lifeworld in turn informs the speaking of words about God (interpretation of scripture and tradition in doctrines). It is an ongoing process of embodying theology and theologising (from) the body in the process of making enquiries within theological anthropology about the embodied existence of human and non-human creatures before God (Meiring 2014:284).

\section{Acknowledgements Competing interests}

The author declares that he has no financial or personal relationships which may have inappropriately influenced him in writing this article.

\section{References}

Ashley, B.M., 1985, Theologies of the body: Humanist and Christian, The Pope John Center, Braintree, MA.

Bethlehem, L., 2006, Skin tight: Apartheid, literary culture and its aftermath, Unisa Press, Pretoria/Koninklijke Brill NV, Leiden.
Bodymaps, n.d., On longer life: Ongoing developments of body mapping, viewed 11 May 2009, from http://www.bodymaps.co.za

Brett-MacLean, P., 2009, 'Body mapping: Embodying the self living with HIV/AIDS', Canadian Medical Association Journal 180(7), 740-741. http://dx.doi.org/ 10.1503/cmaj.090357

Damasio, A., 2012, Self comes to mind. Constructing the conscious brain, Vintage Books, London.

Fassin, D., 2007, When bodies remember: Experiences and politics of AIDS in South Africa, University of California Press, Berkeley, CA/Los Angeles, CA. http://dx.doi. org/10.1525/california/9780520244672.001.0001

Gendlin, E., 1991, 'Thinking beyond patterns: Body, language and situations', in B. den Ouden \& M. Moen (eds.), The presence of feeling in thought, pp. 25-151, Peter Lang, New York, NY.

Gendlin, E., 1996, Focusing-oriented psychotherapy: A manual of the experiencing method, The Guildford Press, New York, NY.

Gendlin, E., 1997, 'How philosophy cannot appeal to experience, and how it can', in D.M. Levin (ed.), Language beyond postmodernism: Saying and thinking in Gendlin's philosophy, pp. 3-41, Northwestern University Press, Evanston, IL.

Holmes, R., 2007, The Hottentot Venus: The life and death of Saartjie Baartman: Born 1789- buried 2002, Jonathan Ball, Johannesburg/Cape Town.

Isherwood, L. \& Stuart, E., 1998, Introducing body theology, Pilgrim, Cleveland, OH.

Kelsey, D.H., 2009, Eccentric existence: A theological anthropology, vol. 1 \& 2 Westminster John Knox Press, Louisville, KY.

Koch, S.C., Caldwell, C. \& Fuchs, T., 2013, 'In body memory and embodied therapy', Body, Movement and Dance in Psychotherapy 8(2), 82-94. http://dx.doi.org/10.1 080/17432979.2013.775968

Lakoff, G. \& Johnson, M., 1999, Philosophy in the flesh: The embodied mind and its challenge to Western thought, Basic Books, New York, NY.

LeRon Shults, F., 2003, Reforming theological anthropology: After the philosophical turn to relationality, William B. Eerdmans Publishing Company, Grand Rapids, MI.

Meiring, J.J.S., 2014, 'Theology in the flesh: Exploring the corporeal turn from a southern African perspective', PhD dissertation, Faculties of Theology, Vrije Universiteit, Amsterdam, University of Pretoria, Pretoria.

Meiring, J. \& Müller, J.C., 2010, 'Deconstructing the body: Body theology, embodied pastoral anthropology and body mapping', Verbum et Ecclesia 31(1), 7 pages. http://dx.doi.org/10.4102/ve.v31i1.367

Meyburgh, T., 2006, 'The body remembers: body mapping and narratives of physical trauma', MA thesis, Dept. of Psychology, University of Pretoria.

Murphy, N., 2006, Bodies and souls, or spirited bodies? Cambridge University Press, Cambridge. http://dx.doi.org/10.1017/CBO9780511802805

Nelson, J.B., 1978, Embodiment: An approach to sexuality and Christian theology, Augsburg Publishing House, Minneapolis, MN.

Nelson, J.B., 1992, Body theology, Westminster John Knox Press, Louisville, KY.

Nelson, J.B., 2004, Thirst: God and the alcoholic experience, Westminster John Knox Press, Louisville, KY.

Ng'wesheni, A.M., 2002, Rediscovering the human: The quest for a Christo-theological anthropology in Africa, Peter Lang, New York, NY.

Ouzgane, L., 2002, 'Guest editorial: An introduction', The Journal of Men's Studies 10(3), 243-245. http://dx.doi.org/10.3149/jms.1003.243

Pinn, A., 2010, Embodiment and the new shape of Black theological thought, New York University Press, New York, NY.

Paul, J., II., 2006, Man and women He created them: A theology of the body, Pauline Books \& Media, Boston, MA.

Rabaté, J-M., 1996, The ghosts of modernity, The University Press of Florida, Gainesville, FL.

Ruthrof, H., 2000, The body in language, Cassell, London.

Sheets-Johnstone, M., 2009, The corporeal turn: An interdisciplinary reader, Imprint Academic, Exeter.

Smells like screen spirit, 2011, The sentiment of the flesh (Le sentiment de la chair) Review, viewed 27 May 2013, from http://smellslikescreenspirit.com/2011/07/ sentiment-of-the-flesh-the-lesentiment-de-la- chair-review/

Solomon, J., 2007, 'Living with X': A body mapping journey in the time of HIV and AIDS. Facilitator's guide, Regional Psychosocial Support Initiative (REPSSI), Johannesburg.

Todres, L., 2011, Embodied enquiry: Phenomenological touchstones for research psychotherapy and spirituality, Palgrave Macmillan, New York, NY.

Van Huyssteen, J.W., 2006, Alone in the world? Human uniqueness in science and theology. The Gifford Lectures, Eerdmans, Grand Rapids, MI.

Wildman, W.J., 2009, Science and religious anthropology: A spiritually evocative naturalist interpretation of human life, Ashgate, Farnham. 